\title{
PENGARUH PENDEKATAN MULTIREPRESENTASI TERHADAP KEMAMPUAN KOGNITIF SISWA DALAM PEMBELAJARAN FISIKA
}

\author{
Khilman Najib ${ }^{1}$., Joko Siswanto ${ }^{2}$., Joko Saefan ${ }^{3}$ \\ ${ }^{1}$ Program Studi Pendidikan Fisika Universitas PGRI Semarang, Jl. Lontar No. 1 Semarang \\ ${ }^{1}$ e-mail: najibkhilman97@gmail.com
}

\begin{abstract}
Submit: 08-06-2020 Revisi: 10-07-2020 Diterima: 13-07-2020 Diterbitkan: 17-08-2020
\end{abstract}
\begin{abstract}
Abstrak: Penelitian ini bertujuan untuk mengetahui pengaruh pendekatan multirepresentasi terhadap ke-mampuan kognitif siswa dalam pembelajaran Fisika. Desain penelitian ini adalah true experimental design yang berbentuk pretest-posttest control design. Populasi dalam penelitian ini ada-lah 30 siswa kelas VII MTs NU Ma'rifatul Ulum. Teknik pengambilan sampel melalui simple random sampling; diperoleh 15 siswa kelas VII-A sebagai kelas eksperimen dan 15 siswa kelas VII-B sebagai kelas kontrol. Berdasarkan analisis data; nilai pre-test pada kelas eksperimen ada-lah 35,47 dan kelas kontrol adalah 26,4; sedangkan nilai post-test pada kelas eksperimen adalah 63,47 dan kelas kontrol adalah 38. Instrumen penelitian yang digunakan adalah lembar tes ke-mampuan kognitif dan keterlaksanaan pembelajaran. Dari hasil pre-test dan post-test yang di-peroleh dari kedua kelas tersebut menunjukkan bahwa ada pengaruh yang signifikan kemampu-an kognitif siswa pada kelas eksperimen dibandingkan kelas kontrol. Analisis statistik menunjuk-kan nilai thitung 0,00< ttabel 0,05 dengan taraf signifikansi $=0,05$, sehingga menolak H0 dan meneri-ma Ha. Adanya perbedaan yang signifikan antara kelas eksperimen dan kelas kontrol maka pen-dekatan multirepresentasi memberikan pengaruh terhadap kemampuan kognitif siswa dalam pembelajaran fisika.
\end{abstract}

Kata kunci: Kemampuan Kognitif Siswa, Pendekatan Multirepresentasi

\section{THE EFFECT OF MULTIREPRESENTATION APPROACHES ON STUDENTS' COGNI-TIVE ABILITIES IN PHYSICS LEARNING}

\begin{abstract}
This study aims to determine the effect of the Multirepresentation approach on the students' cog-nitive abilities in learning Physics. The design of this research is true experimental design in the form of pretest-posttest control design. The population in this study were 30 students of class VII MTs NU Ma'rifatul Ulum. Sampling through simple random sampling; obtained 15 students of class VII-A as an experimental class and 15 students of class VII-B as a control class. The re-search instrument used was a cognitive ability test and learning observation. Based on data analysis, the experimental class pretest scores were 35.47 and the control class 26.4. While the mean score of the experimental class posttest was 63.47 and the control class was 38. From the pretestposttest results obtained from both classes showed that there was a significant influence on students' cognitive abilities in the experimental class compared to the control class. Statisti-cal analysis shows the value of count $0.00<$ ttable 0.05 with a significance level of $=0.05$, thus re-jecting $\mathrm{HO}$ and accepting Ha. There is a significant difference between the experimental class and the control class then the multirepresentation approach gives an influence on students' cognitive abilities in learning physics.
\end{abstract}

Keywords: Student Cognitive Ability, Multirepresentation Approach 
Rahmawati, Mastuang, Suyidno, \& Sunarti. (2020). Kelayakan Bahan Ajar Fisika Berbasis Inkuiri Terbimbing untuk Melatihkan Keterampilan Proses Sains Peserta Didik

\section{PENDAHULUAN}

Fisika adalah salah satu cabang ilmu sains yang mempelajari tentang fenomena alam terkait dengan materi dan energi. Fenomena ini dibentuk dari berbagai besaran fisis (Suhandi \& Wibowo, 2012; Suyidno et al., 2018; 2019). Untuk menjelaskan fenomena yang muncul, para ilmuwan membangun konsep-konsep dan teori-teori. Pengetahuan konseptual dalam fisika berupa simbol yang abstrak (Ismet, 2013). Simbol yang abstrak menyebabkan siswa kesulitan memahami konsep fisika. Ketidakmampuan siswa melakukan representasi yang berbeda dalam memahami konsep fisika nampaknya menjadi kesulitan bagi siswa. Selain itu, pembelajaran fisika di sekolah bersifat tradisional, di mana pembelajaran berpusat pada guru dengan proses transfer pengetahuan dari guru kepada siswa (Suhandi \& Wibowo, 2012).

Pembelajaran fisika menuntut siswa agar menguasai representasi-representasi yang berbeda; seperti percobaan, grafik, konseptual, rumus, gambar, dan diagram (Mahardika, 2013). Pengajaran dengan multi representasi memberikan konteks yang kaya bagi siswa untuk memahami suatu konsep (Izsak \& Saherin dalam Rosyid, 2013). Tampilan berbagai representasi dalam penanaman konsep dapat membantu siswa memahami konsep yang sedang dipelajari. Penanaman konsep ini terkait dengan setiap siswa memiliki kemampuan spesifik yang lebih menonjol dibanding kemampuan lainnya. Ada siswa lebih menonjol pada kemampuan verbalnya dibanding kemampuan spasial dan kuantitatifnya, tetapi ada juga yang sebaliknya. Penyajian konsep yang hanya ditekankan pada satu atau dua representasi saja, maka akan menguntungkan sebagian siswa dan tidak menguntungkan siswa yang lainnya. Ketika penyajian konsep hanya dinyatakan dalam representasi verbal, maka siswa yang lebih menonjol kemampuan spasialnya akan sulit memahami konsep yang disajikan (Suhandi \& Wibowo, 2012).

Ranah kognitif berkenaan dengan hasil belajar intelektual meliputi aspek mengingat (C1), mengerti (C2), memakai (C3), menganalisis (C4), menilai (C5), dan mencipta (C6) (Anderson \& Karthwohl dalam Widianingtiyas dkk., 2015). Keenam aspek di atas disusun berdasarkan struktur piramidal dari aspek yang paling sederhana hingga paling kompleks. Kemampuan kognitif siswa dalam penelitian ini diukur dari hasil belajar kognitifnya. Penggunaan multi representasi yang baik menjadi kunci keberhasilan kemampuan kognitif siswa dalam keilmuan tertentu. Pendekatan multirepresentasi siswa adalah hal yang perlu diketahui oleh guru karena dapat dijadikan bahan evaluasi bagi guru terhadap hasil pembelajarannya. Berdasarkan hasil evaluasi tersebut, guru dapat merencanakan pendekatan pembelajaran yang tepat. Guru dapat menggunakan pendekatan lain yang tepat dan bisa juga menggunakan lebih dari satu pendekatan dalam mengajar. Penggunaan berbagai macam pendekatan dapat meningkatkan kemampuan kognitif siswa. Oleh karena itu; tujuan penelitian ini adalah mengetahui pengaruh pendekatan multirepresentasi terhadap kemampuan kognitif siswa dalam pembelajaran Fisika.

\section{METODE PENELITIAN}

Metode penelitian ini menggunakan True Experimental Design dengan bentuk "Pretest-Posttest Control Design". Populasi dalam penelitian ini adalah siswa kelas VII MTs NU Ma'rifatul Ulum. Pengambilan sampel melalui simple random sampling; diperoleh 15 siswa kelas VII-A sebagai kelas eksperimen dan 15 siswa kelas VII-B sebagai kelas kontrol. Teknik Simple Random Sampling adalah suatu teknik tanpa pertimbangan tertentu (Sugiyono, 2017). Sebelum penelitian, telah dikembangkan instrumen tes kemampuan kognitif siswa dan lembar pengamatan keterlaksanaan pembelajaran; kemudian dilakukan uji validasi oleh 3 pakar pembelajaran fisika dan telah dinyatakan valid oleh pakar.

Penelitian diawali dengan meminta siswa kelas eksperimen maupun kelas kontrol untuk mengerjakan pre-test kemampuan kognitif. Tes ini untuk menggukur kemampuan mengingat, memahami/mengerti, menerapkan, menganalisis, mengevaluasi, dan mencipta. Selanjutnya; peneliti menerapkan pembelajaran fisika dengan pendekatan multirepresentasi pada kelas eksperimen dan pembelajaran konvensional pada kelas kontrol. Selama pembelajaran, 2 orang pengamat berbagi tugas menilai keterlaksanaan pembelajaran mengacu instrumen pengamatan keterlaksanaan pembelajaran. Instrumen ini terdiri dari 20 pernyataan yang mencakup keterlaksanaan kegiatan pembelajaran. Pada akhirnya; pembelajaran diakhiri dengan 
meminta siswa pada kedua kelompok untuk mengerjakan kembali post-test kemampuan kognitif. Selanjutnya data pre-test dan post-test kemampuan kognitif dilakukan uji prasyarat melalui uji normalitas dan uji homogenitas, kemudian dilanjutkan uji hipotesis. Sementara, data keterlaksanaan pembelajaran dianalisis secara deskriptif kualitatif.

\section{HASIL DAN PEMBAHASAN}

Kemampuan kognitif siswa diukur melalui pre-test and post-test yang terdiri dari 6 indikator kemampuan kognitif. Hasil analisis kemampuan kognitif pada kelas eksperimen dan kelas kontrol disajikan di Tabel 1.

Tabel 1 Perbandingan Nilai Rata-rata

\begin{tabular}{lccc}
\hline \multicolumn{1}{c}{ Kelas } & Pre-test & Post-test & Peningkatan (\%) \\
\hline Eksperimen & 35,47 & 63,47 & 78,00 \\
Kontrol & 26,40 & 38,00 & 43,93 \\
\hline
\end{tabular}

Berdasarkan Tabel 1; hasil pre-test menunjukkan kemampuan kognitif siswa pada kelas eksperimen maupun kelas kontrol pada awalnya masih rendah. Sebaliknya; hasil post-test pada kelas eksperimen menunjukkan kenaikan sebesar 78\%. Kenaikan tersebut lebih besar dibandingkan kelas kontrol; di mana kenaikannya hanya $43,93 \%$. Berarti; peningkatan kemampuan kognitif siswa yang mengikuti pembelajaran fisika dengan pendekatan multirepresentasi lebih baik daripada pembelajaran konvensional.

Signifikansi dari perbedaan kemampuan kognitif kelas eksperimen dengan kelas kontrol dilihat dari hasil uji secara statistik. Uji ini diawali dengan uji prasyarat; yaitu data pre-test dan post-test kemampuan kognitif siswa dilakukan uji normalitas dan homogenitas yang hasilnya disajikan pada Tabel 2 dan Tabel 3.

Tabel 2. Hasil Uji Normalitas Shapiro-Wilk

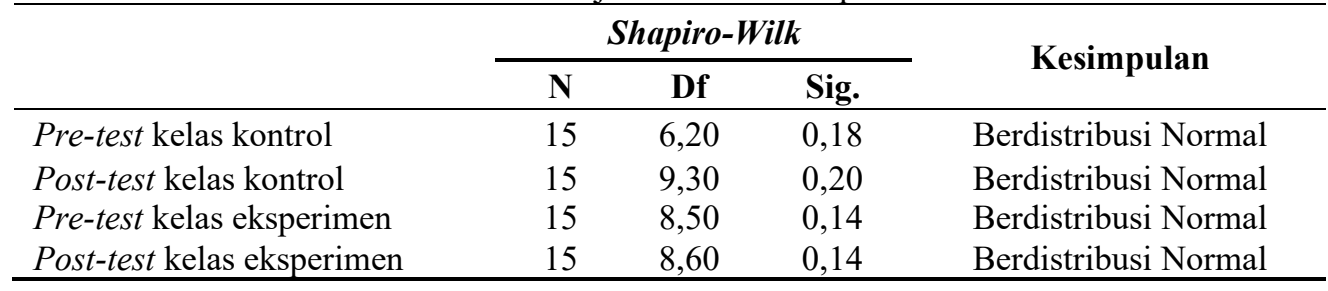

Tabel 3. Hasil Uji Homogenitas Oneway ANOVA

\begin{tabular}{cccccc}
\hline & Levene Statistic & df1 & df2 & Sig. & Kesimpulan \\
\hline Pre-test & 0,503 & 1 & 28 & 0,416 & Homogen \\
Post-test & 0,077 & 1 & 28 & 0,783 & Homogen \\
\hline
\end{tabular}

Berdasarkan Tabel 2; nilai probabilitas pada uji normalitas Shapiro-Wilk dapat dilihat pada kolom sig. (signifikansi). Kelas kontrol diperoleh nilai sig. $=0,18$ pada hasil pre-test dan sig. $=0,20$ pada hasil post-test; mengingat nilai sig. $>0,05$ maka data sampel pada kelas kontrol adalah berdistribusi normal. Kelas eksperimen memperoleh nilai sig. $=0,14$ pada hasil pre-test maupun post-test; mengingat nilai sig. $>$ 0,05 maka data sampel pada kelas eksperimen berdistribusi normal. Selain itu, Tabel 3 memperlihatkan hasil uji Oneway ANOVA berbantuan SPSS 22 diperoleh nilai sig. $=0,48$ untuk pre-test dan sig. $=0,78$ untuk post-test. Nilai sig. $>0,05$; berarti kelas eksperimen maupun kontrol mempunyai varian yang homogen. Dengan demikian; data pre-test dan post-test tersebut dapat dilanjutkan uji-t hipotesis menggunakan independent sample t-test berbantuan SPSS 22 untuk mengetahui signifikansi dari perbedaan antara dua sampel yang tidak berpasangan. Hasil analisis disajikan pada Tabel 4.

Tabel 4 Hasil Uji Hipotesis Independent Sample T-Test

\begin{tabular}{lccl}
\hline \multicolumn{1}{c}{ Varian } & T & df2 & Sig. \\
\hline Varian sama diasumsikan & 7,84 & 28,00 & 0,00 \\
Varian sama tidak diasumsikan & 7,84 & 27,83 & 0,00 \\
\hline
\end{tabular}

Tabel 4 memperlihatkan hasil analisis independent sample t-test diperoleh nilai sig. $=0,00<0,05$; ini berarti uji hipotesis dalam penelitian ini memiliki pengaruh yang signifikan. Hasil uji hipotesis inde- 
Rahmawati, Mastuang, Suyidno, \& Sunarti. (2020). Kelayakan Bahan Ajar Fisika Berbasis Inkuiri Terbimbing untuk Melatihkan Keterampilan Proses Sains Peserta Didik

pendent sample t-test menolak $\mathrm{H}_{0}$ dan menerima $\mathrm{H}_{\mathrm{a}}$. Karena adanya perbedaan yang signifikan antara kelas kontrol dan kelas eksperimen, maka pendekatan multirepresentasi berpengaruh terhadap kemampuan kognitif siswa kelas VII MTs NU Ma'rifatul Ulum. Hal ini diperkuat hasil uji $n$-gain yang disajikan pada Tabel 5 .

Tabel 5. Hasil Uji Gain Kemampuan Kognitif Siswa.

\begin{tabular}{ccccc}
\hline Kelas & Pre-test & Post-test & $<\mathbf{g}>$ & Kriteria \\
\hline Kontrol & 26,40 & 38,00 & 0,20 & Rendah \\
Eksperimen & 35,47 & 63,47 & 0,81 & Sedang \\
\hline
\end{tabular}

Berdasarkan Tabel 5; kemampuan kognitif siswa kelas kontrol sebelum dan sesudah pembelajaran dengan pendekatan konvensional adalah 26,40 dan 38,00 dengan peningkatannya dalam kategori rendah; sementara kemampuan kognitif pada kelas eksperimen sebelum dan sesudah diterapkan multirepresentasi adalah 35,47 dan 63,47 dengan peningkatannya dalam kategori tinggi. Peningkatan kemampuan kognitif siswa ini tidak terlepas dari peran guru dalam mengajarkan fisika dengan baik. Hal ini dapat dilihat dari hasil analisis keterlaksanaan pembelajaran pada Tabel 6 .

Tabel 6. Keterlaksanaan Kegiatan Pembelajaran

\begin{tabular}{lcccc}
\hline \multicolumn{1}{c}{ Kelas } & Skor Perolehan & Skor Maksimal & Nilai & Kriteria \\
\hline Kontrol & 64 & 80 & 80,00 & Baik \\
Eksperimen & 79 & 80 & 98,75 & Sangat Baik \\
\hline
\end{tabular}

Tabel 6 menunjukkan guru mampu mengajarkan fisika materi suhu dan perubahannya baik pada kelas eksperimen maupun kelas kontrol dengan baik. Meskipun guru telah mengajar pada kelas eksperimen dan kelas kontrol dengan baik sesuai RPP; namun kemampuan kognitif siswa (Tabel 5) pada kelas eksperimen lebih baik dari kelas kontrol. Melalui pendekatan multirepresentasi; guru mampu merepresentasi konsep-konsep fisika dalam bentuk grafik, tabel, gambar, dan video untuk meminimalisir kesulitan belajar siswa. Dengan demikian; siswa menjadi lebih termotivasi dan aktif dalam mengingat, memahami, menerapkan, menganalisis, mengevaluasi, maupun menciptakan bentuk atau pola dari konsep sebelumnya. Akibatnya, penguasaan konsep dan kemampuan kognitif siswa lebih optimal.

Penguasaan konsep dan kemampuan kognitif siswa lebih optimal dibuktikan dengan meningkatnya nilai post-test siswa pada kelas eksperimen yang menggunakan pembelajaran dengan pendekatan multirepresentasi. Selain peningkatan dari hasil belajar yang tercermin dari meningkatnya nilai post-test, juga ada peningkatan konsistensi ilmiah yang tercermin dari meningkatnya pemahaman materi siswa terhadap materi yang diajarkan. Hal ini didukung hasil penelitian Sari dkk. (2018) bahwa penerapan pendekatan multirepresentasi mampu meningkatkan prestasi belajar dan konsistensi ilmiah pada materi elastisitas. Siswa lebih tertarik dan aktif selama kegiatan pembelajaran untuk mencapai suatu tingkat pemahaman materi pelajaran sehingga siswa lebih mudah mempelajari konsep fisika dalam berbagai bentuk representasi. Hasil penelitian Doyan dkk. (2015) juga menunjukkan pendekatan multirepresentasi dapat meningkatkan pemahamaman siswa, keterlibatan siswa selama proses belajar, dan berpengaruh terhadap hasil belajar fisika. Pendekatan multirepresentasi mampu menciptakan proses pembelajaran yang memberikan representasi untuk membantu melengkapi proses kognitif. Keunggulan tersebut dibuktikan dengan adanya peningkatan hasil belajar siswa pada kelas eksperimen. Selain itu, beberapa siswa juga mengatakan jika pembelajaran menggunakan pendekatan multirepresentasi lebih memudahkan mereka dalam memahami konsep daripada pendekatan konvensional yang diterapkan oleh guru sebelumnya.

Kelemahan penelitian ini adalah minimnya alokasi waktu pembelajaran untuk merepresentasikan konsep-konsep fisika dalam berbagai bentuk. Akibatnya; siswa yang belum terbiasa akan membutuhkan waktu lebih lama untuk memahami konsep-konsep yang direpresentasikan ke dalam bentuk lainnya. Namun demikian; penerapan pendekatan multirepresentasi memberikan pengaruh terhadap kemampuan kognitif siswa dibandingkan dengan pendekatan konvensional. Melalui pendekatan multirepresentasi, siswa terlibat aktif dalam menemukan solusi masalah. Selain itu, siswa mampu meningkatkan kemampuan kognitifnya untuk memahami dan menerjemahkan konsep-konsep yang masih bersifat abstrak. 


\section{SIMPULAN}

Hasil analisis dan pembelajaran menunjukkan ada pengaruh signifikan pada pendekatan multirepresentasi terhadap kemampuan kognitif siswa di MTs Ma'rifatul Uluma pada materi suhu dan perubahannya. Hal ini terlihat nilai gain pada kelas eksperimen sebesar 0,81 dengan kategori tinggi dan kelas kontrol sebesar 0,20 dengan kategori rendah. Selain itu, hasil uji independent sample t-test menunjukkan adanya perbedaan yang signifikan antara kelas kontrol dan kelas eksperimen. Pendekatan multirepresentasi memudahkan guru dalam merepresentasi konsep fisika dalam bentuk grafik, tabel, gambar, dan video sehingga mampu meningkatkan kemampuan kognitif siswa.

\section{UCAPAN TERIMA KASIH}

Terima kasih penulis ucapkan kepada Prodi Pendidikan Universitas PGRI Semarang Fisika dan MTs NU Ma'rifatul Ulum yang membantu terlaksananya proses penelitian skripsi ini.

\section{DAFTAR PUSTAKA}

Doyan, A., Taufik, M., \& Anjani, R. (2018). Pengaruh Pendekatan Multi Representasi Terhadap Hasil Belajar Fisika Ditinjau dari Motivasi Belajar Siswa. Jurnal Penelitian Pendidikan IPA (JPPIPA), 4(1), 35-45.

Ismet. (2013). Dampak Perkuliahan Mekanika Berbasis Multipel Representasi terhadap Kecerdasan Spasial Mahasiswa Calon Guru. Jurnal Pendidikan Fisika Indonesia, 9, 132-143.

Mahardika, I. K. (2013). Penerapan Model Pembelajaran Interaktif Berbasis Konsep untuk Meningkatkan Kemampuan Representasi Verbal, Matematik, dan Gambar Fisika Siswa Kelas VIII-A MTs N 1 Jember Tahun Pelajaran 2012/2013. Jurnal Pendidikan Fisika, 2(3), 272-277.

Rosyid. et al. (2013). Meningkatkan Hasil Belajar Fisika Menggunakan Model Orientasi IPA (PBL dan Multi Representasi) pada Konsep Mekanika di SMA. Jurnal Pancaran, 2(3), 1-12.

Sari, A.P., Feranie, S., \& Karim, S. (2015). Penerapan Pembelajaran Berbasis Masalah dengan Pendekatan Multirepresentasi untuk Meningkatkan Prestasi Belajar dan Konsistensi Ilmiah Berbasis Multirepresentasi pada Materi Elastisitas. Jurnal Penelitian dan Pengembangan Pendidikan Fisika, 1(2), 45-50.

Sugiyono. (2017). Metode Penelitian Pendidikan. Bandung: Alfabeta.

Suhandi, A. \& Wibowo, F. C. (2012). Pendekatan Multirepresentasi Dalam Pembelajaran UsahaEnergi Dan Dampak Terhadap Pemahaman Konsep Mahasiswa. Jurnal Pendidikan Fisika Indonesia, 8, 1-7.

Suyidno, Nur, M., Yuanita, L., Prahani, B.K., \& Jatmiko, B. (2018). Effectiveness of Creative Responsibility Based Teaching (CRBT) Model on Basic Physics Learning to Increase Student's Scientific Creativity and Responsibility. Journal of Baltic Science Education, 17(1), 136-151.

Widianingtiyas, L. Siswoyo \& Bakri, F. (2015). Pengaruh Pendekatan Multi Representasi dalam Pembelajaran Fisika Terhadap Kemampuan Kognitif Siswa SMA. Jurnal Penelitian dan Pengembangan Pendidikan Fisika, 1(1). 
Rahmawati, Mastuang, Suyidno, \& Sunarti. (2020). Kelayakan Bahan Ajar Fisika Berbasis Inkuiri Terbimbing untuk Melatihkan Keterampilan Proses Sains Peserta Didik 